\title{
TRANSMISSION OF THE KUR'AN ACCORDING TO CHRISTIAN WRITERS*
}

\section{PART II}

$I_{N}$ considering the question of the transmission of the Kur'ān according to Christian writers, the reader will feel that he is more in the domain of historical facts than in that of the precarious Hadith; unfortunately, any information found in books written at the very beginning of Isläm, is naturally scanty. In face of the conflagration which, in a few years shook the political foundations of the near East, Christian writers were more anxious to save their skin from the onslaughts of the Ishmaelites and Hagarians - as they used to call the early Arabs-than to study the kind of religion they professed. Syriac books, however, contain important data which throw great light upon our subject, and overshadow by their antiquity the tardy Muslim Hadith of the ninth century.

The first account is, in order of date, the colloquy or the discussion which took place in Syria between 'Amr b. Al' $\mathrm{A}$ s and the Monophysite Patriarch of Antioch, John I, in the eighteenth year of the Hijra (Sunday, 9 May, 639 A.D.). It has been published from a MS. in the British Museum dated 874 A.D. by F. Nau, in the Journal Asiatique. The Patriarch was summoned before 'Amr along with five bishops and a great number of notable Christians, and some days after the discussion, the Patriarch and the bishops wrote a careful report of what had happened, and sent it to the Christians of Mesopotamia, asking them to "pray for the illustrious Amir, that God might grant him wisdom and enlighten him in what is the will of the Lord." The questions that "Amr asked and the introductory words of the colloquy are as follows:

\footnotetext{
*Concluded from July. Reprinted by permission from The Journal of the Manchester Egyptian and Oriental Society, 1916.

† Mars-Avril, 1915, p. 248 sq.
} 
We inform your love that on the ninth of this month of May, on the holy Sunday, we went in before the glorious General Amir. The blessed Father of all was asked by the Amir whether the Gospel which is in the hands of all who are called Christians in all the world, was one and without any difference whatever. The blessed Patriarch answered . . . Then the Amir asked why if the Gospel was one, faith was different; and the Patriarch answered

The Amir then asked, "What do you think of the Christ? Is He God or not? Our Father then answered . . ." And the glorious Amir asked him this question, "When the Christ, whom you call God, was in the womb of Mary, who was holding and governing heaven and earth?" Our blessed Father answered . . . And the glorious Amir said, "What were the views and the belief of Abraham and Moses?" Our blessed Father answered . . . And the Amīr said, "Why did they not write clearly and show their belief about the Christ?" and our blessed Father answered . . . When the Amir heard these things, he only asked whether the Christ born of Mary was God, and whether God had a son, and whether this could be proved from the Torah and by reason. And our blessed Father said, "Not only Moses, but all the holy prophets have previously related these points of the Christ . . ." And the glorious Amir said that he would not accept the proof of these points by quotations from the prophets; but only required that it should be proved to him by quotations from Moses that the Christ was God. And the blessed Father among other quotations, brought forth the following from Moses, "Then the Lord from before the Lord brought down fire and brimstone upon Sodom and Gomorrah;"* and the glorious Amir required that this quotation should be shown to him in the Book. And our Father showed it to him without delay, $f$ in the complete Greek and Syriac Books. In that assembly, some Hagarians (Muslims) were present with us, and they saw the

*Genesis xix, 24.

†Nau translates the Syriac expression dla tūhhäya by "sans erreur possible," instead of "easily, without delay." 
text ${ }^{*}$ with their own eyes, and the existence of the glorious name of the Lord twice. And the Amir called a certain Jew, who was believed by the Jews to be a Knower of Books, and asked him if this was literally true in the Torah; and the Jew answered "I do not know with certainty."

Then the Amir digressed from this point and asked about the laws of the Christians, how and what they were, and if they were written in the Gospel; and asked, too, if a man dies and leaves sons or daughters, with a wife, a mother, a sister and a cousin, how would his heritage be divided between them? . . . A long discussion ensued; and not only the best-known men among the Hagarians (Muslims) were present there, but also the heads and the rulers of the town, and of the faithful and Christ-loving tribes: Tannūkhians, Tu'ians, and "Akulians. $\dagger$ And the glorious Amir said, "I want you to do one of these three things: either to show me that your laws are written in the Gospel, and that you are following them, or to follow the laws of the Hagarians (Muslims)." And our Father answered, "Our laws, the laws of us Christians, are just, equitable, and in harmony with the teaching and the Commandment of the Gospel, the prescriptions of the Apostles and the laws of the Church." It is with this that the first gathering of that day ended, and up to now we have not been again before the Amir."

From this important document written in the fifth year of 'Umar's Caliphate and possibly $\ddagger$ some months after the terrible year of ashes, and of plague, $\S$ we can safely infer (1) that no Bible was translated into Arabic at that early period; $\|$ ( 2 ) that the teaching of the Kur'an on the matter of heritages, the denial of the divinity and the death of Christ and on the subject of the Torah, which is given a marked predilection in Muhammad's oracles, was familiar to the muslims present in the discussion; (3)

"Lit. "the writings."

†Christian Arab tribes of Southern Syria.

IIt is very difficult to determine with exactitude the chronology of events at this period of Arab conquests.

SCf. W. Muir, The Caliphate: its Rise, Docline and Fall, 1915, p. 153 a.

IICf. in Patrologia Orientalis, V, p. 51, the Arabic text edited by B. Evetts. 
that no Islāmic Book was mentioned when the colloquy took place; (4) that some of the early Arab conquerors knew how to read and to write.*

About A.D. 647, in the first years of 'Uthmān's Caliphate, the famous Patriarch of Seleucia, Isho'yahb III, said in one of his letters which he wrote when still bishop of Nineveh, "In excusing yourselves falsely, you might perhaps say, or the Heretics might make you say, 'What has happened was due to the order given by the Arabs' (Tayyāyé); but this would not be true at all, because the Arab Hagarians (Muslims) do not help those who attribute sufferings and death to God, the Lord of everything." $\dagger$ From what we know of Isho'yahb, he would have surely mentioned or quoted the Islāmic Book, had he known it, or even heard of it ( $c f .$, Ibid p. 251).

The anonymous writer printed by Guidi $\ddagger$ knows nothing about a sacred Book of Islām in A.D. 680, at the time of the Umayyad Caliphate of Yazīd, son of $\mathrm{Mu}^{6} \bar{a} w i a h$. He believed the Arabs to be simply the descendents of Ishmael, who professed the old Abrahamic faith, and gives Muhammad as a mere general, without any religious character. "Then God raised against (the Persians) the sons of Ishmael like the sand of the sea-shores, with their leader Muhammad . . As to the $\mathrm{Ka}$ 'bah we cannot know what it was, except in supposing that the blessed Abraham having become very rich in possessions, and wanting to avoid the envy of the Canaanites, chose to dwell in the distant and large localities of the desert; and as he was living under tents, built that place for the worship of God and the offering of sacrifices; for this reason, this place received its title of our days, and the memory of the place was transmitted from generation to generation with the evolution of the Arab race. It was not, therefore, new for the Arabs to worship in that place, but their worship therein was from the beginning of their days; in this, they were rendering honour to the father of the head of their race . . . and Madinah was

\footnotetext{
-These, however, might have been Jewish or Christian renegades.

†Edit. Duval Corp. Script. Christ. Orient, tomus LXIV, p. 97.

$\ddagger$ Chronica Minora, Ibid. tomus IV, pp. 30 and $\mathbf{3 8 .}$
} 
called after Madian, the fourth son of Abraham from Keturah; the town is also called Yathrib."

John Bar Penkāyé* has some interesting records in his Chronicle about the early Arab conquests and the famous Shurät of whose exploits he was an eye-witness, but he does not know that these Arabs had any sacred Book in A.D. 690, when he was writing, under the Caliphate of 'Abdul-Mälik. "The Arabs, as I have said above, had a certain order from the one who was their leader, in favour of the Christian people and the monks; they held also, under his leadership, the worship of one God, according to the customs of the Old Covenant; at the outset they were so attached to the tradition of Muhammad who was their teacher, that they inflicted the pain of death upon any one who seemed to contradict his tradition $\dagger$. . . Among them there were many Christians, some from the Heretics, $\ddagger$ and some from us." $\S$

From these quotations and from many passages of some contemporary writers, it is evident that the Christian historians of the whole of the seventh century had no idea that the "Hagarian" conquerors had any sacred Book; similar is the case among historians and theologians of the beginning of the eighth century. It is only towards the end of the first quarter of this century that the Kur'ann became the theme of conversation in Nestorian, Jacobite, and Melchite ecclesiastical circles. The Christians, in spite of the intolerant attitude of Muslim Caliphs and governors, continued to write, frequently under pain of death, many polemical lucubrations in refutation of the sacred Book of Islām, which met with a swarm of answers from the Muslim side. For the end of the century the reader will find good information in Steinschneider's well-known work.\| Some years before this date two important publications, not yet edited, saw the light, viz., the Refutation of the Kur'ān by Abū Nōh, secretary to the

*A. Mingana, Sources Syriaques, vol. I, pt. x, p. 146 sqq.

†Notice the Syriac word Mfashilmannutha "tradition" in its rapport with "a written thing."

†i.e., Monophysites.

\&i.e., Nestorians.

\|Pol. und A pol. Littertur in Arab. Sprache, 1877. 
Governor of Mosul,* and the apology of Christianity by Timothy, Nestorian Patriarch of Seleucia, recently made known by Braun in Oriens Christianus. $†$

So far as the transmission of the Kur'ān is concerned, by far the most important work is the apology of al-Kindi, critically studied in 1887 by W. Muir.

Casanova writes: "Il faut, je crois, dans l'histoire critique du Coran, faire une place de premier ordre au Chrétien Kindite." \& According to this Kindite, who wrote some forty years before Bukhāri, the history of the

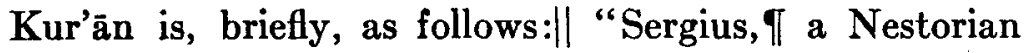
monk, was excommunicated for a certain offence; to expiate it he set out on a mission to Arabia; in Maccah he met Muhammad with whom he had intimate converse. At the death of the monk, two Jewish doctors, 'Abdallah and $K a \mathrm{a} b$, ingratiated themselves with Muhammad and had great influence over him. Upon the Prophet's death, and at the instigation of the Jews, 'Ali refused to swear allegiance to Abu Bakr, but when he despaired of succeeding to the Caliphate, he presented himself before him, forty days (some say six months) after the Prophet's death. As he was swearing allegiance to him, he was asked, ' $O$ Father of Hasan, what hath delayed thee so long?' He answered, 'I was busy collecting the Book of the Lord, for that the Prophet committed to my care.' The men present about $\mathrm{Abu}$ Bakr represented that there were scraps and pieces of the Kur'ān with them as well as with 'Ali; and then it was agreed to collect the whole from every quarter together. So they collected various parts from the memory of individuals (as Sūratul-Barā'ah, which they wrote out at the dictation of a certain Arab

*Assemani, B. O. III, 1, 218.

†1901, p. 150.

$\$$ The Apology of al-Kindy written at the court of al-Mämün oirca, A.D. 830. An excellent edition of this work has recently appeared in Egypt in the "Nile Mission Press," whose chairman is Dr. S. M. Zwemer.

SIbid. p. 119.

$\| C f$. Muir, Ibid. p. 70 sg.

TThe predominant role of this monk will be carefully set forth in our future studies. The Arab authors who scarcely knew any other language besides the Arabic, confused his name with the title Bhira given by Arameans to every monk; see Nau, Expansion Nestorienne en Arie, 1914, pp. 218-223, who showed how misleading was the practice of some scholars who simply availed themselves of the tardy Muslim Hadith. 
from the desert), and other portions from different people; besides that which was copied out from tablets of stone, and palm-leaves, and shoulder-bones, and such like. It was not at first collected in a volume, but remained in separate leaves. Then the people fell to variance in their reading; some read according to the version of 'Ali, which they follow to the present day; some read according to the collection of which we have made mention; one party read according to the text of ibn Mas'ūd, and another according to that of Ubayy ibn $\mathbf{K a}^{\prime} \mathbf{b}$.

"When 'Uthmān came to power, and people everywhere differed in their reading, "Ali sought grounds of accusation against him, compassing his death. One man would read a verse one way, and another man another way; and there was change and interpolation, some copies having more and some less. When this was represented to 'Uthmann, and the danger urged of division, strife, and apostacy, he thereupon caused to be collected together all the leaves and scraps that he could, together with the copy that was written out at the first. But they did not interfere with that which was in the hands of 'Ali, or of those who followed his reading. Ubayy was dead by this time; as for ibn Mas'ūd, they demanded his exemplar, but he refused to give it up. Then they commanded Zaid ibn Thābit, and with him 'Abdallah ibn 'Abbās, to revise and correct the text, eliminating all that was corrupt; they were instructed, when they differed on any reading, word, or name, to follow the dialect of the Kuraish.

"When the recension was completed, four exemplars were written out in large text; one was sent to Maccah, and another to Madinah; the third was despatched to Syria, and is to this day at Malatya; the fourth was deposited in Küfah. People say that this last copy is still extant at Küfah, but this is not the case, for it was lost in the insurrection of Mukhtār (A.H. 67). The copy at Maccah remained there till the city was stormed by $\mathrm{Abu}$ Sarāyah (A.H. 200); he did not carry it away; but it is supposed to have been burned in the conflagration. The Madinah exemplar was lost in the reign of terror, that is, in the days of Yazid b. Mu'āwiah (A.H. 60-64). 
"After what we have related above, 'Uthmãn called in all the former leaves and copies, and destroyed them, threatening those who held any portion back; and so only some scattered remains, concealed here and there, survived. Ibn Mas'ūd, however, retained his exemplar in his own hands, and it was inherited by his posterity, as it is this day; and likewise the collection of "Ali has descended in his family.*

"Then followed the business of Hajjāj b. Yūsuf, who gathered together every single copy he could lay hold of, and caused to be omitted from the text a great many passages. Among these, they say, were verses revealed concerning the House of Umayyah with names of certain persons, and concerning the House of 'Abbās also with names. $\dagger$ Six copies of the text thus revised were distributed to Egypt, Syria, Madinah, Maccah, Küfah, and Basrah.f After that he called in and destroyed all the preceding copies, even as 'Uthmān had done before him. The enmity subsisting between 'Ali and Abū Bakr, 'Umar and 'Uthmān is well known; now each of these entered in the text whatever favoured his own claims, and left out what was otherwise. How, then, can we distinguish between the genuine and the counterfeit? And what about the losses caused by Hajjāj? The kind of faith that this tyrant held in other matters is well-known; how can we make an arbiter as to the Book of God a man who never ceased to play into the hands of the Umayyads whenever he found opportunity?"

Then al-Kindi, addressing his Muslim friend, says: "All that I have said is drawn from your own authorities, and no single argument has been advanced but what is based on evidence accepted by yourselves; in proof thereof, we have the Kur'ān itself, which is a confused heap, with neither system nor order."

It should be noticed here that something which might be termed an answer to al-Kindi from the Muslim side has

*These details will be studied in future.

†Cf. Geschichte des Qorāns, 1909, p. 255 (edit. Schwally). s3.

†This fact receives a direct confirmation from ibn Dukmak and Makrizl quoted on p. 
been discovered among the Arabic manuscripts of the John Rylands Library, Manchester. In a MS., dated 616 of the Hijrah, I found the Kitäbud-Dini wad-Daulah, "Book of Religion and Empire," written in A.D. 855, by the physician 'Ali b. Rabbanat-Tabari, at the request of the Caliph Mutawakkil. It is an official Apology of Islām, appearing at an interval of some twenty years after the Apology of Christianity by al-Kindi. On the important point of the transmission of the Kur'ann, the author is content to appeal to the piety, asceticism, and devotion of the early Caliphs and disciples of the Prophet, and says, "If such people may be accused of forgery and falsehood, the disciples of the Christ might also be accused of the same." This is a meagre answer to the historical indictments of al-Kindi.

We trust that the Arabists will rightly value the outstanding importance of this new work, written before all the traditional compilations of the second half of the ninth century. So far as the religious system of Islam is concerned, it is of an unparalleled significance, containing, as it does, many traditions dealing with the Prophet, his religion and his disciples, which are not found elsewhere. I have prepared the text for the press and translated it with some critical annotations required by its antiquity and its extrinsic and intrinsic importance.* After a long introduction in which the author praises Isläm, gives good advice to be followed in discussions, and shows the laudable zeal of the Caliph Mutawakkil in the propagation and vindication of his faith, he sets forth the reasons why people of the tolerated cults do not embrace Islām and why they should embrace it, and because the greater number of the non-Muslim population were Christian, he addresses the Christians more frequently; in the second rank come Jews, Magians, Hindoos, and Dualists, who, however, are attacked more sharply. The order of the chapters is as follows:

(a) Different forms of historical facts and common agreement. (b) Criteria for the verification of historical facts. (c) The Prophet called to the unity of God and to

\footnotetext{
"The work will be published for the Governors of the John Rylends Library by the Manchester University Press.
} 
what all the prophets have believed. (d) Merits of the ways of acting and the prescriptions of the Prophet. (e) Miracles of the Prophet which the "People of the Book" have rejected. ( $f$ ) The Prophet foretold events hidden from him, which were realised in his lifetime. (g) Prophecies of the Prophet, which were realised after his death. (h) The Prophet was an unlettered man, and the Book which God revealed to him is, therefore, a sign of prophetic office. (i) The victory won by the Prophet is a sign of prophetic office. ( $j$ ) The disciples of the Prophet and the eye-witnesses of his career were most honest and pious: (1) ascetisicm of the Bakr; (2) asceticism of 'Umar; (3) asceticism of 'Ali; (4) asceticism of 'Umar b. 'AbdulAziz, of 'Abdallah b. 'Umar b. Khattāb, and of some other pious Muslims. ( $k$ ) If the Prophet had not appeared the prophecies of the prophets about him and about Ishmael would have been without object. $(l)$ Prophecies of the prophets about him: Moses, David, Isaiah, Hosea, Micah, Habakkuk, Zephaniah, Zechariah, Jeremiah, Ezekiel, Daniel, Christ and His disciples. (m) Answer to those who have blamed the prescriptions of Islām. (n) Answer to those who are shocked that the Prophet should have innovated and changed some prescriptions of the Torah and the Gospel. (o) Answer to those who pretend that no one but the Christ has mentioned the Resurrection. ( $p$ ) Conclusion.

In his biblical quotations, the author refers to the version of a certain "Marcus the Interpreter," of which we are still unable to find any trace in any other book, either Syriac or Arabic.

Apart from the question of an official edition of the Kur'ān being unknown to Christian writers till the second half of the eighth century, the idea gathered from the ancient Christian compositions is in complete agreement with "the theory that Islām is primarily a political adventure;"* and as in the Semitic mind political adventures cannot succeed without some "persuasions" to heaven, and "dissuasions" from hell, it is the merit of the first Caliphs to have so skilfully handled, after their master

*D. S. Margoliouth, in Encyclopedia of Religion and Ethics, VIII, 879. 
and in imitation of "the people of the Book," the spiritual instrument which was easy and handy and which brought them such wonderful results. (Ist der Islām) "Keineswegs als ein Religionssystem ins Leben getreten, sondern als ein Versuch sozialistischer Art, gewissen überhandnehmenden irdischen Miss-ständen entgegenzutreten.”*

\section{Conclusion}

From all the above facts and documents, any impartial critic, interested in the Kur'anic literature of the Muslim world, can draw his own conclusions. If we may express our opinion, we would be tempted to say:

(1) If all signs do not mislead us, very few oracular sentences, if any, were written in the time of the Prophet. The kind of life that he led, and the rudimentary character of reading and writing in that part of the world in which he appeared, are sufficient witnesses in favour of this view. Our ignorance of the Arabic language in that early period of its evolution is such that we cannot even know with certainty whether it had any writing of its own in Maccah and Madinah. If a kind of writing existed in these two localities, it must have been something very similar to the Estrangelo or the Hebraic characters. Ibn Khaldūn learnt the "art of writing" from the Christians of the town of Hirah, and the first Kuraishite who learned it was Sufyān b. Umayyah.f Further, Hirschfeld§ has already noted that "The Qoran, the text-book of Islām is in reality nothing but a counterfeit of the Bible;" this verdict applies in a more accentuated manner to the compilation of the Kur'ān. No disciple of Moses or of Christ wrote the respective oracles of these two religious leaders in their lifetime, and probably no such disciple did so in the case of the Prophet. A man did not become an acknowledged prophet in a short time; years elapsed before his teaching was considered worth preserving on parchment. Lam-

"H. Grimme, Mohammed, I., Munster, p. 14; Munchen, p. 50.

†Mukaddimah, p. 965 (edit. Beirat).

tWe cannot enter into details on this subject which is a digression from the Kur'anic theme.

$\$ N$ ew researches into the comparition and exegesis of the Qorain, p. 11. 
mens* has observed, "Le Prophète s'était fait intimer par Allah (Qoran, lxxv. 16-17) l'ordre de ne pas se presser pour éditer le Qoran, comme recueil séparé. La précaution était prudente, étant donné le caractère inconsistant de certaines révélations."

(2) Some years after the Prophet's death many of his companions, seeing that his cause was really flourishing and gathering considerable momentum by means of able generals, vied in writing down, each one in his own sphere, the oracles of their master. This work gave them prestige, and sometimes high posts which they could scarcely have obtained otherwise; in this series is to be included the compilation of Ubayy b. Ka'b, Ibn Mas'ūd, 'Uthmān b. 'Affān, and probably 'Ali b. Abi Talib. When 'Uthmān obtained the Caliphate, his version was naturally given a royal sanction, to the detriment of the three other recensions. The story of the Kuraishite scribes who were told by 'Uthmān to write down the Revelation in the dialect of Kuraish, ought to be discarded as half legendary. We all know how ill adapted was the Arabic writing even of the eighth century to express all the phonetic niceties of the new philological schools; it is highly improbable, therefore, that it could express them in the first years of the Hijrah. Moreover, a very legitimate doubt can be entertained about the literary proficiency of all the collectors mentioned in the tardy hadith of the ninth century. Most of them were more tribal chieftains than men of literature, and probably very few of them could even read or write; for this reason the greater part of their work must have been accomplished by some skilled Christian or Jewish amanuensis, converted to Islām.

(3) This last work of Companions and Helpers does not seem to have been put into book form by 'Uthmān, but was written on rolls of parchment, on suhufs, and it remained in that state till the time of Abdul-Mālik and Hajjāj ibn Yūsuf. At this time, being more familiar with writing by their intercourse with the Jews and Christians of the enlightened capital of Syria, and feeling

*Fätima et les filles de M1ahomet, p. 119. 
more acutely the necessity of competing on even terms with them, the Caliph and his powerful lieutenant, gave to those rolls the character and the continuity of a book, and very possibly, added new material from some oral reciters of the Prophet's oracular sentences. At any rate, the incident of both Hajjāj and 'Uthmān writing copies of the Kur'ann and sending them to the head-provinces is very curious. We will conclude the first chapter of this enquiry with the following sentences by Professor Casanova* to which we fully adhere:

"Mais les fragments d'os, de palmier, etc., sur lesquels étaient écrits, de la main des secrétaires, les versets dictés par le Prophète, et qui avaient servi à la première recension, sous Aboa Bakr, que sont-ils devenus? Je me refuse à croire qu'ils auraient été détruits. Quel extraordinaire sacriliège! Comment aurait-on pu traiter ainsi ces témoins les plus directs de la révélation. Enfin s'ils avaient existé, comment expliquer la crainte que 'Oumar et Aboa Bakr témoignèrent de voir le Coran disparaître par la mort des récitateurs? S'ils n'avaient pas existé, tous les passages si nombreux où le Coran est désigné (par le mot Kitāb) auraient été introduits après coup! Voilà bien des contradictions inhérentes au récit traditionnel, et toutes se résolvent par la conclusion que j'adopte: Le Coran a été mis, par écrit, pour la première fois par les soins d'al Hajjāj qui probablement s'appuyait sur la légende d'un prototype dâ à 'Outhmân. Il est possible qu'il y ait eu des transcriptions antérieures, mais sans caractère officiel, et par conséquent sans unité."

Alphonse Mingana.

*Ibid., pp. 141-142. 